\title{
Fatty acid profile, color and lipid oxidation of organic fermented sausage during chilling storage as influenced by acid whey and probiotic strains addition
}

\author{
Karolina Maria Wójciak*, Małgorzata Karwowska, Zbigniew Józef Dolatowski
}

University of Life Sciences in Lublin - Dept. of Meat Technology and Food Quality - 8 Skromna - 20-704 - Lublin

- Poland.

*Corresponding author <karolina.wojciak@up.lublin.pl>

Edited by: Paulo Cesar Sentelhas

\begin{abstract}
Organic fermented sausages typically spoil during long-term storage due to oxidative rancidity. The application of natural antioxidants to meat stuffing is a major practice intended to inhibit the oxidation process and color changes. This study aimed to assess the effect of two unusual starter cultures: three probiotic strains (Lactobacillus casei LOCK 0900, Lactobacillus casei LOCK 0908 and Lactobacillus paracasei LOCK 0919) and lactic acid bacteria from acid whey on model fermented sausage type products focusing on oxidative stability by measuring instrumental color ( $\mathrm{L}^{*}, \mathrm{a}^{*}, \mathrm{~b}^{*}$ values), conjugated dienes (CD), TBARS immediately after 21 days of ripening $(0)$ and after 90 and 180 days of refrigerated storage $\left(4^{\circ} \mathrm{C}\right)$. Determination of fatty acid composition, in meat product was performed after ripening and after 180 days of storage. At the end of the storage period, the salted sausages were characterized by the same content of polyunsaturated fatty acids (PUFA) compared to cured samples. The addition of acid whey and a mixture of probiotic strains to nitrite-free sausage formulation was barely able to protect lipids against oxidation in comparison to nitrite during vacuum storage. Surprisingly, the use of acid whey has an influence on the desired red-pinkish color of organic fermented sausage after
\end{abstract} ripening and after 180 days of storage period.

Keywords: oxidation stability, uncured, functional food, antioxidant whey and whey proteins as antioxidants was investigated by several authors (Lasik et al., 2011; Liu et al., 2007; Tong et al., 2000; Worobiej et al., 2008). Whey protein was found in muscle food as a strong antioxidant which has the ability to chelate pro-oxidant transition metals by lactoferrin and serum albumin and free radical scavenging by cysteine and tyrosine. Moreover, whey proteins can also stimulate the growth of some Bifidobacterium and Lactobacillus probiotic strains (Kozioł et al., 2013).

Since there is a lack of knowledge about the effectiveness of acid whey and a mixture of probiotic strains to retard the oxidation processes in fermented meat product, this study aimed to assess the effect of a starter culture of probiotic strains as well as acid whey on model fermented sausage type products in terms of oxidative stability, by measuring instrumental color, conjugated dienes (CD), TBARS and fatty acid composition after 21 days of ripening (0) and during 180 days of refrigerated storage $\left(4^{\circ} \mathrm{C}\right)$.

\section{Materials and Methods}

in muscle proteins (Zhang et al., 2007).

Fermented meat products typically spoil during long-term storage due to oxidative rancidity. Oxidative processes in fermented meat products lead to the degradation of unsaturated fatty acids, cholesterol and proteins (including pigments), which, in turn, contribute to the deterioration in color, texture (cross linking binding) and flavor (Zanardi et al., 2002). Moreover, the presence of sodium chloride can have an accelerating effect on lipid oxidation (Higgins et al., 1999).

The application of natural antioxidants to the meat stuffing is a major practice to inhibit the oxidation process and color changes (Pegg et al., 2000). The application of

\section{Preparation of acid whey}

Fresh organic acid whey was obtained from cottage cheese production from the local traditional dairy then exposed to the process of natural fermentation. Next, it was heated to a temperature of $40^{\circ} \mathrm{C}$. When the coagulation process finished, the whey was separated from the lump. The count of lactic acid bacteria (LAB) in acid whey was $7.0 \log \mathrm{CFU} \mathrm{mL} \mathrm{mL}^{-1}$. A microbiological test to determine the LAB was performed according to ISO, 2002. processing plant. Fresh organic milk not preserved was 


\section{Characterisation and preparation of probiotic strains}

The Lactobacillus casei LOCK 0900, Lactobacillus casei LOCK 0908 and Lactobacillus paracasei LOCK 0919 strains (Motyl et al., 2009a,b,c) were isolated from the feces of healthy infants. In vitro tests conducted on probiotic strains revealed the strains' resistance to low $\mathrm{pH}$ and bile salts (Cukrowska et al., 2009) and showed antagonistic activity against pathogenic bacteria. Moreover, the probiotic strains also synthesize bacteriocins resistant to proteolytic enzymes, e.g., biosurfactans with described antimicrobial function. A favorable impact of Lactobacillus casei LOCK 0900 strain on atopic dermatitis caused by cow's milk protein allergy in children was also discovered (Cukrowska et al., 2010). Cukrowska et al. (2010) proved for in vivo experiments that a mixture of $L$. casei LOCK 0900, L. casei LOCK 0908 and L. paracasei LOCK 0919 strains affects the immune system by inducing $\mathrm{T}_{\mathrm{H}} 1$ and regulatory cytokine production and by suppressing pro-allergic response better as compared to a single strain.

The probiotic material comprised a mixture of probiotic strains Lactobacillus casei LOCK 0900, Lactobacillus casei LOCK 0908 and Lactobacillus paracasei LOCK 0919 according to the method described by Jaworska et al. (2011).

\section{Sausage formulation}

The materials were obtained from Polish Large White purebred swine in an organic system. The live weight of the animals was $120-130 \mathrm{~kg}$. The animals were fed with feed from their own farms, consisting of organic cereal, namely wheat (Triticum aestivum), barley (Hordeum vulgare L.), oats (Avena sativa) and peas (Pisum sativum), grain and green matter. Meat and pork backfat were purchased from an organic meat manufacturer at $48 \mathrm{~h}$ postmortem. Pork meat (ham muscle $850 \mathrm{~g} \mathrm{~kg}^{-1}$ ) was first minced using a knife and chilled at $4{ }^{\circ} \mathrm{C}$. Pork backfat (150 $\left.\mathrm{g} \mathrm{kg}^{-1}\right)$ was also minced using a knife. The pork meat was divided into four equal samples.

The curing mixture (994-995 $\mathrm{g} \mathrm{kg}^{-1}$ sodium chloride, $5-6 \mathrm{~g} \mathrm{~kg}^{-1}$ sodium nitrite) was added to one of the stuffings at a number of $28 \mathrm{~g} \mathrm{~kg}^{-1}$ of the meat (control - cured sample). Grecian sea salt without nitrite and nitrate (salt specification) was added to the remaining stuffing samples at a level of $28 \mathrm{~g} \mathrm{~kg}^{-1}$ of the sausage batter. The meat was then stored at $4{ }^{\circ} \mathrm{C}$ for $48 \mathrm{~h}$. Next, each meat sample was minced separately using universal machine $8 \mathrm{~mm}$ discs and mixed with minced backfat.

Four batches were prepared: control with the curing mixture and $50 \mathrm{~g} \mathrm{~kg}^{-1}$ of water (C), organic sample with sea salt and $50 \mathrm{~g} \mathrm{~kg}^{-1}$ of water (S), organic sample with sea salt and acid whey added in a ratio of $50 \mathrm{~g} \mathrm{~kg}^{-1}$ (AW), organic sample with sea salt and $2 \mathrm{ml} \mathrm{kg}^{-1}$ starter cultures of probiotic strain added (P). Glucose was added to all treatments at a level of $6.0 \mathrm{~g} \mathrm{~kg}^{-1}$. The mixes were stuffed into casings $(65 \mathrm{~mm})$ and matured according to the following procedure: $24 \mathrm{~h}$ at $19-20{ }^{\circ} \mathrm{C}$ and $90-92 \%$ relative humidity, followed by a gradual decrease in temperature to $18-19{ }^{\circ} \mathrm{C}$ and relative humidity to $65-80 \%$, and then the sausage was maintained under these conditions for 19 days, giving a total of 21 days of maturation.

Following maturation, the sausages were divided into 12 samples (four treatments $\times$ three storage times), vacuum packed in low-density polyethylene (LDPE) bags and stored in a refrigerator $\left(4^{\circ} \mathrm{C}\right)$ for 180 days. Each sample was analyzed for conjugated dienes, TBARS values and $\mathrm{L}^{*}, \mathrm{a}^{*}, \mathrm{~b}^{*}$ color parameters immediately after maturing (day 0), and after 90 and 180 days of chilling storage. Fatty acid composition was measured at 0 and 180 days of refrigerated storage.

\section{Composition of fatty acids}

An analysis of fatty acid composition was carried out on total lipids extracted according to Folch et al. (1957) after methyl-esterification according to the procedure described in Method 969.33 (AOAC, 2005). A gas chromatographic analysis was performed as described by Official Method 996.06 (AOAC, 2005) using a chromatograph equipped with a capillary fused silica column. Flame ionization detection was used. The temperature of both the injection port and the detector was $260{ }^{\circ} \mathrm{C}$. The carrier gas was helium, $75.8 \mathrm{kPa}$ and the sample volume $0.5 \mu \mathrm{L}$.

Fatty acid methyl esters were identified by comparison with previously run standards, alone or together with samples. The fatty acid methyl esters were quantified as a percentage of total methyl esters. Fatty acids were reported as a percentage of total fatty acids determined. Results were expressed as saturated fatty acids (SFA), monounsaturated fatty acids (MUFA) and polyunsaturated fatty acids (PUFA); and the PUFA/SFA (P/S), PUFA/SFA-stearic acid (C18:0) and MUFA + PUFA/ SFA-stearic acid (C18:0), n-6/n-3 ratios were calculated.

\section{Analysis of conjugated dienes}

The formation of conjugated dienes was determined as described by Srinivasan et al. (1996). Meat samples $(3.0 \mathrm{~g})$ were suspended in $30 \mathrm{~mL}$ of distilled water and homogenized to form a "smooth slurry". A 3 $\mathrm{mL}$ aliquot of this suspension was mixed with $30 \mathrm{~mL}$ of extracting solution (3:1 hexane : isopropanol) for $1 \mathrm{~min}$. After centrifugation at $2,000 \mathrm{x}$ g for $5 \mathrm{~min}$, the absorbance of the supernatant was read at $233 \mathrm{~nm}$. The concentration of the conjugated diene was calculated using the molar extinction coefficient of $25.000 \mathrm{M}^{-1} \mathrm{~cm}^{-1}$ and

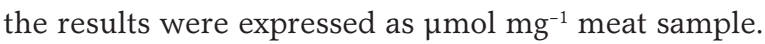

\section{Determination of TBARS}

Lipid oxidation was determined by assessing TBARS values according to the Pikul et al. (1989) method. The color intensity produced in the reaction of malondialdehyde with 2-thiobarbituric acid was measured using the Nicolet Evolution 300 spectrophotometer at a wavelength of $532 \mathrm{~nm}$. TBARS values were expressed in mg malondialdehyde per $1 \mathrm{~kg}$ of meat product. 


\section{Instrumental color measurement}

Instrumental color measurements were taken immediately after slicing the sample after 90 and 180 days of storage. This means that the samples were protected from progressive pigment degradation due to oxygen, light and higher temperature. After slicing, the samples were covered with a single layer of food wrap. Five readings were taken for each sample. The $\mathrm{L}^{*}, \mathrm{a}^{*}, \mathrm{~b}^{*}$ values and reflectance values between 390 and $700 \mathrm{~nm}$ were measured using an X-Rite 8200 colorimeter and the D65 illuminant, $8 \mathrm{~mm}$ port size, and a $10^{\circ}$ standard observer. Color coordinates were determined using the CIELAB system. The results were expressed as lightness $\left(\mathrm{L}^{*}\right)$, redness $\left(\mathrm{a}^{*}\right)$ and yellowness $\left(\mathrm{b}^{*}\right)$.

\section{Statistical analysis}

The data reported were analyzed by two-way analysis of variance (ANOVA) at $p \leq 0.05$. The significance of the differences between treatments at the same storage time and the same treatments at differ- ent storage times was determined $(p \leq 0.05)$ using the T-Tukey's range test. All data presented the averages from a minimum of two experiments conducted in duplicate.

\section{Results and discussion}

\section{Composition of fatty acid}

Lipid oxidation is a major cause of chemical fermented meat product spoilage and is considered one of the main limiting shelf-life factors of these products (Frankel 1998). Fatty acids of model fermented sausage shown in Table 1. After ripening, there was no difference $(p>0.05)$ in fatty acid content with one exception in MUFA content between control sample (C) and sample with acid whey addition (AW). There were no differences $(p>0.05)$ between percentage of polyunsaturated fatty acids (PUFA) and 18:2 (n-6), 18:3 (n-3); and between samples with curing salt compared to organic sausage samples.

Table 1 - Fatty acid composition (means \pm standard deviations) of uncured model fermented sausage after 21 days of ripening $(0)$ and 180 days of chilling storage (\% of total fatty acids).

\begin{tabular}{|c|c|c|c|c|c|}
\hline Fatty acid & Storage & $\mathrm{C}$ & $S$ & AW & $\mathrm{P}$ \\
\hline & day & & & & \\
\hline \multirow{2}{*}{$16: 0$} & 0 & $20.27 \pm 0.39^{a B}$ & $21.05 \pm 0.34^{\mathrm{aA}}$ & $21.14 \pm 1.28^{\mathrm{aB}}$ & $20.37 \pm 0.08^{\mathrm{aB}}$ \\
\hline & 180 & $25.84 \pm 0.53^{\mathrm{aA}}$ & $22.19 \pm 0.88^{\mathrm{bA}}$ & $26.45 \pm 0.30^{\mathrm{aA}}$ & $25.81 \pm 0.76^{a A}$ \\
\hline \multirow{2}{*}{$18: 0$} & 0 & $8.77 \pm 0.16^{\mathrm{aB}}$ & $9.40 \pm 0.21^{\mathrm{aB}}$ & $9.31 \pm 0.74^{\mathrm{aB}}$ & $9.18 \pm 0.47 \mathrm{aB}$ \\
\hline & 180 & $12.72 \pm 0.83^{\mathrm{aA}}$ & $13.10 \pm 0.63^{\mathrm{aA}}$ & $14.19 \pm 0.93^{\mathrm{aA}}$ & $13.57 \pm 0.60^{\mathrm{aA}}$ \\
\hline \multirow{2}{*}{$18: 1(n-9)$} & 0 & $46.57 \pm 0.21^{\mathrm{aA}}$ & $45.56 \pm 0.20^{\mathrm{aB}}$ & $45.14 \pm 0.69^{a A}$ & $45.14 \pm 0.28^{\mathrm{aA}}$ \\
\hline & 180 & $47.21 \pm 0.59^{a A}$ & $52.46 \pm 0.22^{\mathrm{bA}}$ & $46.25 \pm 0.40^{a A}$ & $45.74 \pm 0.03^{\mathrm{aA}}$ \\
\hline \multirow{2}{*}{$18: 2(n-6)$} & 0 & $11.69 \pm 0.10^{\mathrm{aB}}$ & $11.66 \pm 0.14^{\mathrm{aB}}$ & $11.67 \pm 1.27^{\mathrm{aB}}$ & $12.03 \pm 0.18^{a B}$ \\
\hline & 180 & $6.71 \pm 0.55^{\mathrm{aA}}$ & $7.40 \pm 1.25^{\mathrm{aA}}$ & $5.53 \pm 0.27^{\mathrm{aA}}$ & $6.42 \pm 1.29^{\mathrm{aA}}$ \\
\hline \multirow{2}{*}{$18: 3(n-3)$} & 0 & $1.11 \pm 0.04^{\mathrm{aA}}$ & $1.02 \pm 0.24^{\mathrm{aA}}$ & $1.21 \pm 0.19^{\mathrm{aB}}$ & $1.28 \pm 0.04^{\mathrm{aB}}$ \\
\hline & 180 & $0.32 \pm 0.41^{a A}$ & $0.64 \pm 0.15^{\mathrm{aA}}$ & $0.41 \pm 0.03^{\mathrm{aA}}$ & $0.53 \pm 0.17^{a A}$ \\
\hline \multirow{2}{*}{ SFA } & 0 & $31.22 \pm 0.58^{\mathrm{aB}}$ & $32.70 \pm 0.43^{\mathrm{aA}}$ & $32.76 \pm 1.99 \mathrm{aB}$ & $31.95 \pm 0.41^{\mathrm{aB}}$ \\
\hline & 180 & $40.70 \pm 1.49^{a A}$ & $37.51 \pm 1.61^{\mathrm{aA}}$ & $43.00 \pm 1.20^{\mathrm{aA}}$ & $41.59 \pm 1.65^{\mathrm{aA}}$ \\
\hline \multirow{2}{*}{ MUFA } & 0 & $55.86 \pm 0.44^{\mathrm{aB}}$ & $54.53 \pm 0.05^{\mathrm{abA}}$ & $54.17 \pm 0.57^{\mathrm{bB}}$ & $54.62 \pm 0.13^{\mathrm{ab} A}$ \\
\hline & 180 & $51.79 \pm 0.96^{a A}$ & $54.05 \pm 0.30^{a A}$ & $50.81 \pm 1.49^{\mathrm{aA}}$ & $51.06 \pm 0.06^{\mathrm{aA}}$ \\
\hline \multirow{2}{*}{ PUFA } & 0 & $12.82 \pm 0.17^{\mathrm{aB}}$ & $12.71 \pm 0.35^{\mathrm{aB}}$ & $12.98 \pm 1.37^{\mathrm{aB}}$ & $13.36 \pm 0.22^{\mathrm{aB}}$ \\
\hline & 180 & $7.42 \pm 0.55^{a A}$ & $8.18 \pm 1.31^{\mathrm{aA}}$ & $6.15 \pm 0.30^{\mathrm{aA}}$ & $7.29 \pm 1.59^{\mathrm{aA}}$ \\
\hline \multirow{2}{*}{$n-3$} & 0 & $1.11 \pm 0.04^{\mathrm{aB}}$ & $1.02 \pm 0.24^{\mathrm{aA}}$ & $1.21 \pm 0.19 \mathrm{aA}$ & $1.28 \pm 0.04 a^{B}$ \\
\hline & 180 & $0.71 \pm 0.00^{A}$ & $0.79 \pm 0.06^{A}$ & $0.62 \pm 0.03 \mathrm{~A}$ & $0.71 \pm 0.06^{A}$ \\
\hline \multirow{2}{*}{$n-6$} & 0 & $11.69 \pm 0.10^{\mathrm{aB}}$ & $11.66 \pm 0.14^{\mathrm{aB}}$ & $11.73 \pm 1.18^{\mathrm{aB}}$ & $12.03 \pm 0.18^{a B}$ \\
\hline & 180 & $6.71 \pm 0.55^{\mathrm{aA}}$ & $7.40 \pm 1.25^{\mathrm{aA}}$ & $5.53 \pm 0.27^{\mathrm{aA}}$ & $6.42 \pm 1.29^{a A}$ \\
\hline \multirow{2}{*}{$\mathrm{P} / \mathrm{S}$} & 0 & $0.41^{\mathrm{aA}}$ & $0.39^{\mathrm{aA}}$ & $0.40^{\mathrm{aA}}$ & $0.42^{\mathrm{aA}}$ \\
\hline & 180 & $0.18^{\mathrm{aB}}$ & $0.22^{\mathrm{aB}}$ & $0.14^{\mathrm{aB}}$ & $0.18^{\mathrm{aB}}$ \\
\hline \multirow{2}{*}{ P/S-C18:0 } & 0 & $0.57^{\mathrm{aA}}$ & $0.55^{\mathrm{aA}}$ & $0.55^{\mathrm{aA}}$ & $0.59^{\mathrm{aA}}$ \\
\hline & 180 & $0.27^{\mathrm{aB}}$ & $0.34^{\mathrm{aB}}$ & $0.21^{\mathrm{aB}}$ & $0.26^{\mathrm{aB}}$ \\
\hline \multirow{2}{*}{ MUFA+PUFA/SFA-C18:0 } & 0 & $3.06^{\mathrm{aA}}$ & $2.89^{a A}$ & $2.86^{\mathrm{aA}}$ & $2.99^{\mathrm{aA}}$ \\
\hline & 180 & $2.12^{\mathrm{aB}}$ & $2.55^{\mathrm{aA}}$ & $1.98^{\mathrm{aB}}$ & $2.08^{\mathrm{aB}}$ \\
\hline \multirow{2}{*}{$n-6 / n-3$} & 0 & $10.53^{\mathrm{aA}}$ & $11.43^{\mathrm{aA}}$ & $9.69^{a A}$ & $16.90^{\mathrm{aA}}$ \\
\hline & 180 & $9.45 a^{B}$ & $9.37^{\mathrm{aB}}$ & $8.92^{\mathrm{aA}}$ & $9.04^{\mathrm{aB}}$ \\
\hline
\end{tabular}

Means followed by the same letters within columns (lower case letters) and row (capital letters) are not different ( $p<0.05)$. SFA, saturated fatty acids; MUFA, monounsaturated fatty acids; PUFA, polyunsaturated fatty acids; P/S, polyunsaturated fatty acids/saturated fatty acids; P/S-C18:0, polyunsaturated fatty acids/ saturated fatty acids - stearic acid; MUFA+PUFA/SFA-C18:0, monounsaturated fatty acids + polyunsaturated fatty acids/ saturated fatty acids - stearic acid.

C - control with curing mixture and water, S - organic sample with sea salt and water, AW - organic sample with sea salt and acid whey added, $\mathrm{P}$ - organic sample with sea salt and starter cultures of probiotic strain added. 
SFA are considered to raise plasma cholesterol, except for stearic acid which reduces total and LDL cholesterol and the MUFA have a hypocholesterolemic effect, but they do not decrease HDL cholesterol, which protects against cardiovascular diseases (Romero et al., 2013). Thus, the PUFA/SFA-C18:0 ratio and MUFA + PUFA/SFAC18:0 ratio (Romero et al., 2013) were calculated for sausage and are shown in Table 1. The PUFA/SFA-C18:0 and MUFA + PUFA/SFA-C18:0 ratios showed no differences between the products $(p>0.05)$, and they were similar to those reported by other researchers (Romero et al., 2013; Rubio et al., 2008).

Decreased PUFA/SFA-C18:0 and MUFA + PUFA/ SFA-C18:0 ratios were observed for all study samples after 180 days of storage probably as the results of \% SFA of total fatty acids increase and \% PUFA and MUFA of total fatty acids decrease. The sea salt sample (S) had the highest PUFA/SFA-C18:0 and MUFA + PUFA/SFA-C18:0 ratios after ripening and during storage, showing that it had a better nutritional composition as compared with other samples.

After 180 days of chilling storage total SFA content in the sausages was on average $37-43 \%$ and the differences between all of the groups were not significant. The most prevalent SFAs were palmitic (16:0) ( $25 \%$ of total fatty acids) and stearic (18:0) ( $13 \%)$ acids. SFAs have generally been labeled as the culprits for cancer and coronary heart disease, although C18:0 is considered as a neutral fatty acid (Mahan and Escott-Stump, 2000). The content of $\mathrm{C} 16: 0$ fatty acids of treatment $\mathrm{S}$ was lower $(p \leq$ 0.05 ) than treatment $\mathrm{AW}, \mathrm{P}$ and control after storing.

The stable SFA and MUFA amount and the minor decrease in PUFA amount during storage suggested that the oxidation process in the sample with sea salt (S) was lower compared to other samples. The overall mean level of MUFAs was $52 \%$ of total fatty acids, which did not differ between the four groups of sausage samples after 180 days of storage. PUFA content in the sausages was on average $12 \%$ of total fatty acids after ripening, and was influenced ( $p \leq 0.05$ ) by the time of sausage storing but not by the additives.

PUFA decreased $(p \leq 0.05)$ in all samples after 180 days of storage by around $5.62 \%$ for C, $4.53 \%$ for S, 6.83 $\%$ for $\mathrm{AW}$, and $6.07 \%$ for $\mathrm{P}$ sample respectively. It was also noticed, that n- 6 fatty acids decreased in all samples at the end of the storage period by around $4.98 \%$ for C, $4.26 \%$ for S, $6.20 \%$ for AW, and $5.61 \%$ for the P sample respectively. PUFA(s) reduction was due to oxidative and hydrolytic reactions that occurred during storage (YiChen et al., 2008; Rubio et al., 2008; Valencia et al., 2006). Long hydrocarbon chains and high unsaturation of PUFA made them more susceptible to oxidation and hydrolytic reactions than the SFA (Yi-Chen et al., 2008).

PUFA(s) are protective against cardiovascular diseases and they lower total cholesterol (Ander et al., 2003). The PUFA/SFA (P/S) ratio could be a good indicator of the nutritional quality of sausage. The British Department of Health (1990) recommended that the P/S ratio should be above 0.45 . In our study the $\mathrm{P} / \mathrm{S}$ ratios after maturation were a little below 0.45 ; however, after 180 days of chilling storage the $\mathrm{P} / \mathrm{S}$ ratios were below 0.2 in all study samples which indicated the important loss of PUFAs, which is significant for human health. The decline of $\mathrm{P} / \mathrm{S}$ ratio during storage could be caused by loss of PUFAs and increased SFAs.

There was a number of long-chain n-3 PUFAs in the sausages. The overall mean n- 3 fatty-acid content in the sausages was between 1.02 and 1.28 and it was not influenced by the additions but by the storing time of the products. Decreases $(p \leq 0.05)$ in $n-3$ fatty acids in two samples of the control $(\sim 0.42 \%)$ with probiotic strains $(\sim 0.57 \%)$ were observed after chilling storage. The $n-6 / n-3$ ratio should be approximately 1-4/1 because excessively high n-6/n-3 ratio increases cardiovascular risk (Simopoulos, 2002). The results showed an n-6/n-3 ratio between 9.69 and 16.90 after the ripening process and between 8.92 and 9.45 after 180 days of storage. These results could be explained by the decrease $p<$ $0.05)$ in $n-6$ fatty acids in all samples at the end of the storage period by oxidation of linoleic acid $(\mathrm{C} 18: 2, n-6)$.

All sausages produced like the rest of the Western fermented sausages had an excessively high ratio, which was around 10-11/1 due to the extremely low content of n-3 fatty acids (EPA, DHA) (Valencia et al., 2006); thus, they contributed little in terms of dietary recommendations (Romero et al., 2013). Increases in SFA were observed $(p \leq 0.05)$ in all samples $(\sim 10 \%)$, except in the sample with sea salt only (S), in which SFA was constant for all the storage period. In general, while the SFA and MUFA amounts of fermented sausage samples increased during storage, PUFA amounts decreased. The increase in the amounts of SFA and MUFA and decrease in PUFA could be attributable to the oxidation of PUFA during storage.

\section{Analysis of conjugated dienes and TBARS values}

Lipid peroxidation is a major cause of quality deterioration in meat products. Frankel (1998) reported that the formation of conjugated double bonds $(\mathrm{C}=\mathrm{C}-\mathrm{C}=\mathrm{C})$, which is related to the production of hydroperoxides, occurs in the early stage of lipid oxidation. Two treatments with probiotic strains $(\mathrm{P})$ and with sea salt $(\mathrm{S})$ had lower concentrations of conjugated dienes $(p \leq 0.05)$ compared to the control sample (C) after ripening (Table 2). In all treatments, the concentration of conjugated dienes was stable during chilling storage. An exception was a probe with probiotic mixture for which the count of primary oxidation products increased ( $p \leq 0.05)$ during storage.

A higher concentration $(p \leq 0.05)$ of conjugated dienes was observed in sausage with probiotics mixture compared to other samples at the end of the storage pe-

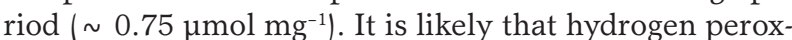
ide produced by probiotic strains could be the source of free radicals which attacked unsaturated fatty acids and transformed them into the conjugated diene forms (Lobo et al., 2010). 
Table 2 - Influence of acid whey and probiotic strains addition and storage time on conjugated diene, TBARS values (means \pm standard deviation).

\begin{tabular}{|c|c|c|c|c|}
\hline & & \multicolumn{3}{|c|}{ Storage time (day) } \\
\hline & & 0 & 90 & 180 \\
\hline \multirow{4}{*}{ Conjugated diene $\left(\mu \mathrm{mol} \mathrm{mg} \mathrm{m}^{-1}\right)$} & $\mathrm{C}$ & $0.25 \pm 0.03^{a}$ & $0.24 \pm 0.02^{\mathrm{ab}}$ & $0.23 \pm 0.02^{\mathrm{a}}$ \\
\hline & $S$ & $0.17 \pm 0.01^{\mathrm{bA}}$ & $0.22 \pm 0.01^{\mathrm{aB}}$ & $0.26 \pm 0.05^{\mathrm{a}}$ \\
\hline & AW & $0.24 \pm 0.04^{a}$ & $0.26 \pm 0.01^{b}$ & $0.27 \pm 0.01^{\mathrm{a}}$ \\
\hline & $\mathrm{P}$ & $0.19 \pm 0.02^{\mathrm{b}}$ & $0.24 \pm 0.02^{\mathrm{ab}}$ & $0.75 \pm 0.01^{\mathrm{b}}$ \\
\hline \multirow{4}{*}{ TBARS values (mg MDA kg-1) } & $\mathrm{C}$ & $1.88 \pm 0.19^{\mathrm{aA}}$ & $1.40 \pm 0.28^{\mathrm{aB}}$ & $1.45 \pm 0.18^{a}$ \\
\hline & $S$ & $2.80 \pm 0.57^{b}$ & $1.97 \pm 0.40^{\mathrm{ab}}$ & $2.46 \pm 0.28^{b}$ \\
\hline & AW & $2.96 \pm 0.14^{\mathrm{bA}}$ & $2.46 \pm 0.23^{\mathrm{bB}}$ & $2.70 \pm 0.29^{b}$ \\
\hline & $\mathrm{P}$ & $2.66 \pm 0.21^{\mathrm{bA}}$ & $2.48 \pm 0.17^{\mathrm{bB}}$ & $2.43 \pm 0.20^{\mathrm{bc}}$ \\
\hline
\end{tabular}

Means followed by the same letters within columns (lower case letters) and row (capital letters) are not different ( $p<0.05)$. C - control with curing mixture and water, $\mathrm{S}$ - organic sample with sea salt and water, AW - organic sample with sea salt and acid whey added, P - organic sample with sea salt and starter cultures of probiotic strain added.

The 2-thiobarbituric acid-reactive substances (TBARS) value is most widely used to determine the later stage of lipid oxidation in meat products. TBARS values are measured mainly for aldehydes, carbonyls and hydrocarbons, which contribute to off-aromas and flavor in meat products (Igene, 1985). Verma and Sahoo (2000) indicate concentrations of secondary lipid oxidation products between 1.0 and $2.0 \mathrm{mg} \mathrm{kg}^{-1}$ as threshold values for rancidity. However, according to Chouliara et al. (2008), the TBARS values of $3.0 \mathrm{mg} \mathrm{kg}^{-1}$ are associated with not only rancidity odor and flavor. Accordingly, only the sample with curing agent in the present study did not exceed the threshold values until the end of the storage period.

The organic sausages $(\mathrm{S}, \mathrm{AW}, \mathrm{P})$ did not exceed the value of $3.0 \mathrm{mg} \mathrm{kg}^{-1}$ which is the indicator of oxidative rancidity of meat products. Incorporating acid whey and probiotic strains in the composition of experimental model fermented sausage had no effect ( $p \leq 0.05)$ on TBARS values at 0,90 and 180 days of storage as compared with the organic sample with sea salt (S) (Table 2). However, higher TBARS values $(p \leq 0.05)$ were observed throughout the chilling storage period in all organic samples ( $\mathrm{S}, \mathrm{AW}, \mathrm{P}$ ) compared to control (with curing salt) probably because $\mathrm{S}, \mathrm{AW}$ and $\mathrm{P}$ had no antioxidant effect $(p \leq 0.05)$ compared to the curing salt treatment $(C)$.

Storage time had significant effects on TBARS measurements in the case of control and two experimental samples with acid whey (AW) and probiotic strains (P). A decrease in TBARS values $(p \leq 0.05)$ was observed in $C_{\text {, }}$ AW and $P$ samples after 180 days of storage. Low TBARS values at the end of storage could also be a result of the reaction of MDA with amino acids, sugar and other compounds in complex (Kolakowska and Deutry, 1983). The highest TBARS values were observed in samples with acid whey after ripening $(2.96 \pm 0.14)$ and at the end of the storage period $(2.70 \pm 0.29)$.

Some authors have pointed out that the presence of other compounds (e.g. amide groups, other aldehydes from smoking process) produced in meat from enzyme proteolysis during ripening could increase the TBARS values (Kolakowska and Deutry, 1983) after ripening (0 day). As expected the uncured sausage samples resulted in the most lipid oxidation. The cured - control (C) had the lowest numerical TBARS value (1.40-1.88 mg MDA $\left.\mathrm{kg}^{-1}\right)$. These results were expressed because nitrite or nitric oxide (derived from nitrite) are considered effective against lipid oxidation in traditionally cured meat products. In general, this additive can chelate iron from heme or can act with lipid peroxyl radicals to form non-radical addition products which cause a break in the radical chain processes of lipid oxidation. Ghiretti et al. (1997) found similar TBARS values during the long-term storage ( 5 months) of fermented sausage containing a number of antioxidants. Zanardi et al. (2002) found for vacuum-packed sausages TBARS values between 0.40 and $3.90 \mathrm{mg} \mathrm{MDA} \mathrm{kg}^{-1}$.

\section{Color parameter}

Oxidative processes in meat and meat products lead to the degradation of lipids and proteins (including pigments) which in turn contribute to the deterioration in color, texture (cross linking binding) and flavor (Zanardi et al., 2002). Lipid oxidation products could interact with heme pigment, resulting in increased susceptibility of heme iron to oxidation and meat product deterioration (Alderon et al., 2003).

All uncured-sausages packed in vacuum maintained good color quality throughout the chilling storage period (Table 3). After the ripening process no differences were found in terms of lightness $\left(\mathrm{L}^{*}\right)$ between sausage samples. After 90 days of chilling storage, a lower $\mathrm{L}^{*}$ value $(p \leq 0.05)$, around 10, was observed for sample with see salt $(S)$ compared to other samples.

At the end of the storage period differences $(p \leq$ $0.05)$ were found between samples. The highest $\mathrm{L}^{*}$ value was observed for the AW sample and the lowest for control $(\mathrm{C})$. The higher $(p \leq 0.05)$ lightness value $\left(\mathrm{L}^{*}\right)$ of probes with acid whey (AW) could be due to the fermentation process which created acid compounds and increased lightness of sausage samples. Sammel and Claus (2003) proved that whey protein concentrates increased lightness compared to the control sausage. There were no differences in lightness of sausage samples from the beginning of the storage period until the end of the process (180 days). 
Table 3 - Influence of acid whey and probiotic strains addition and storage time on color parameters (means \pm standard deviation).

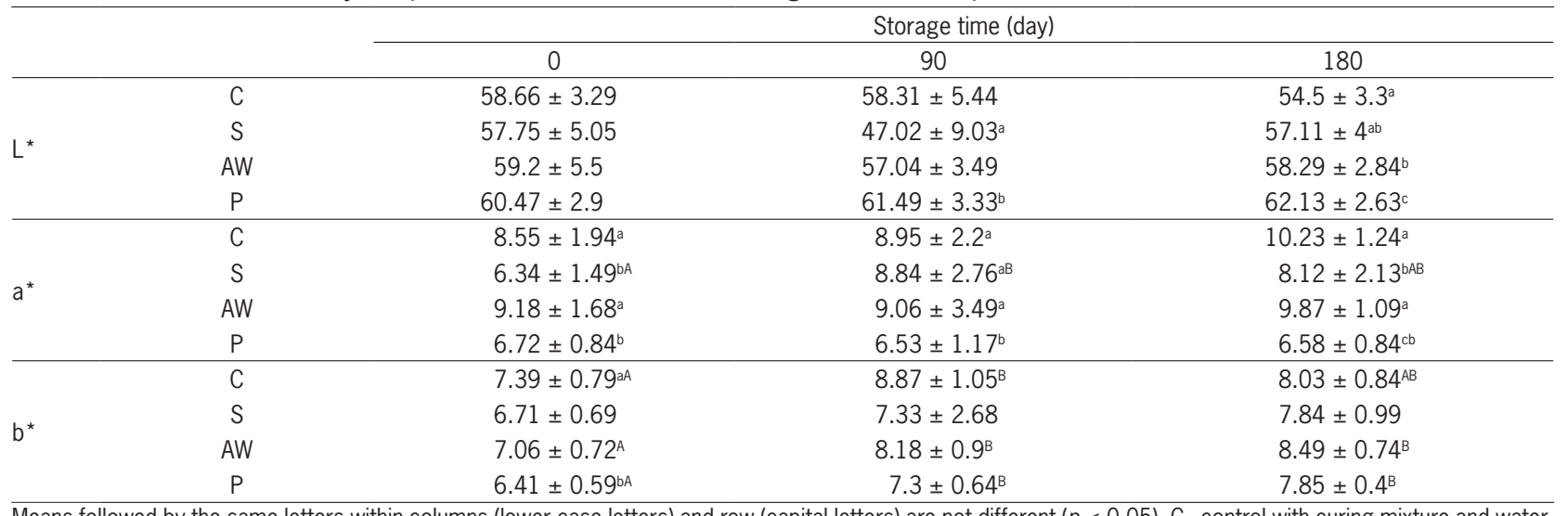

Means followed by the same letters within columns (lower case letters) and row (capital letters) are not different ( $p<0.05)$. C - control with curing mixture and water, $\mathrm{S}$ - organic sample with sea salt and water, AW - organic sample with sea salt and acid whey added, P - organic sample with sea salt and starter cultures of probiotic strain added.

There was no difference $(p \leq 0.05)$ in redness between uncured samples with acid whey (AW) and the cured-control sample during all the storage period. Redness $\left(\mathrm{a}^{*}\right)$ which has been found as an indicator of color stability in meat products during storage remained constant $(p>0.05)$ throughout storage. A slight decrease was observed during the 180 days of storage in the sample with probiotics $(\mathrm{P})$ probably due to the oxidation of lipids (the highest TBARS and conjugated dienes content) initiated heme pigments, oxidation and decreases in the red color of sausages (Carlsen et al., 2005). There is a reason to believe that the mixture of probiotic bacteria could demonstrate the antagonistic effect on the closely related kind and produced the hydrogen peroxide for protection. The hydrogen peroxide produced by probiotic strains can react with myoglobin $\left(\mathrm{Fe}^{2+}\right)$ to ferrylmyoglobin $\left(\mathrm{Fe}^{4+}\right)$, which acts as a pro-oxidant on lipids (Carlsen et al., 2005).

The redness $\left(\mathrm{a}^{*}\right)$ of the organic sausage with acid whey in a slice just after ripening was assessed as high as was the sample with curing mixture addition. During storage the most intensive red coloring was observed for control sample (10.23) and for organic sample with acid whey addition (9.87). Other authors have observed an increasing pinking trend when the whey protein was added (Sammel and Claus, 2003) to the meat.

Yellowness $\left(\mathrm{b}^{*}\right)$ values increased $(p \leq 0.05)$ from 7.38 to 8.50 during the 180 days of storage. Sausage color turned yellow rather than blue. Also Rubio et al. (2008) and García-Esteban (2004) found an increase in yellowness probably due to rancidity during long-term storage of fermented meat products.

More research should be done to verify whether the addition of antioxidants in combination with acid whey and probiotic bacteria improve the oxidative stability of uncured meat product.

\section{Conclusions}

At the end of storage period, the salted sausages had the same content of PUFA as compared to cured samples. However, the results of CD and TBARS measurements suggested that the addition of acid whey and mixture of probiotic strains to nitrite-free sausage formulation were barely able to protect lipids against oxidation in comparison to nitrite during vacuum storage.

The use of acid whey influenced the desired redpinkish color of organic fermented sausage after ripening and after 180 days of storage period.

\section{Acknowledgements}

The research presented in this paper was supported by a Ministry of Agriculture and Rural Development grant, number PKre-029-4-3/12(608).

\section{References}

Alderon, A.L.; Faustman, C.; Liebler, D.C.; Hill, D.W. 2003. Induction of redox instability of bovine myoglobin by adduction with 4-hydroxy-2-nonenal. Biochemistry 42: 4398-4405.

Ander, B.P.; Dupasquier, C.M.C.; Prociuk, M.A.; Pierce, G.N. 2003. Polyunsaturated fatty acids and their effects on cardiovascular disease. Experimental and Clinical Cardiology 8: 164-172.

Association of Official Analytical Chemists [AOAC]. 2005. Official Methods of Analysis. 18ed. AOAC, Gaithersburg, MD, USA.

British Department of Health. 1990. The Care Programme Approach for People with a Mental Illness Referred to the Specialist Psychiatric Services. Join Health/Social Services Circular HC (90) 23/LASS (90) 11. British Department of Health, London, UK.

Carlsen, C.U.; Møller, J.K.S.; Skibsted, L.H. 2005. Heme-iron in lipid oxidation. Coordination Chemistry Reviews 249: 485-498.

Cassens, R. 1995. Use of sodium nitrite in cured meats today. Food Technology 49: 72-115. 
Chouliara, E.; Badeka, A.; Savvaidis, L; Kontominas, M.G. 2008. Combined effect of irradiation and modified atmosphere packaging on shelf-life extension of chicken breast meat: microbiological, chemical and sensory changes. European Food Research and Technology 226: 877-888.

Cukrowska, B.; Motyl, I.; Kozáková, H.; Schwarzer, M.; Górecki, R.K.; Klewicka, E.; Śliżewska, K.; Libudzisz, Z. 2009. Probiotic Lactobacillus strains: in vitro and in vivo studies. Folia Microbiologica 54: 533-537.

Cukrowska, B.; Rosiak, I.; Klewicka, E.; Motyl, I.; Schwarzer M.; Libudzisz, Z.; Kozáková, H. 2010. Impact of HeatInactivated Lactobacillus casei and Lactobacillus paracasei strains on cytokine responses in whole blood cell cultures of children with atopic dermatitis. Folia Microbiologica 55: 277-280.

European Communities. 2006. Directive 2006/52/EC of the European Parliament and of the Council of 5 July 2006 amending Directive 95/2/EC on food additives other than colours and sweeteners and Directive 95/35/EC on sweeteners for use in foodstuffs. Official Journal of the European Union, L 204 of 26.7.2006.

Folch, J.; Lees, M.; Slone-Stanley, G.H. 1957. A simple method for the isolation and purification of total lipid from animal tissues. Journal of Biological Chemistry 226: 497-509.

Frankel, E.N. 1998. Lipid Oxidation. Oily Press, Dundee, Scotland. García-Esteban, M.; Ansorena, D.; Astiasarán, I. 2004. Comparison of modified atmosphere and vacuum packaging for long period storage of dry-cured ham: effects of colour, texture and microbiological quality. Meat Science 67: 5763.

Ghiretti, G.P.; Zanardi, E.; Novelli, E.; Campanini, G.; Dazzi, G.; Madarena, G.; Chizozolini, R. 1997. Comparative evaluation of some antioxidants in salame Milano and Mortadella production. Meat Science 47: 167-176.

Higgins, F.M.; Kerry, J.P.; Buckley, D.J.; Morrissey, P.A. 1999. Effect of $\alpha$-tocopherol acetate supplementation and salt addition on the oxidative stability (TBARS) and warmed-over flavor (WOF) of cooked turkey meat. British Poultry Science 40: 59-64.

Igene, J.O.; Yamauchi, K.; Pearson, A.M.; Gray, J.I.; Aust, S.D. 1985. Mechanisms by which nitrite inhibits the development of warmed-over flavor (WOF) in cured meat. Food Chemistry 18: $1-18$.

International Organization for Standardization [ISO]. 2002. ISO 15214:2002. Microbiology of Food and Animal Feeding Stuffs - Horizontal Method for the Enumeration of Mesophilic Lactic Acid Bacteria - Colony- Count Technique at $30^{\circ} \mathrm{C}$. ISO, Geneva, Switzerland.

Jaworska, D.; Neffe, K.; Kołozyn-Krajewska, D.; Dolatowski, Z.J. 2011. Survival during storage and sensory effect of potential probiotic lactic acid bacteria Lactobacillus acidophilus Bauer and Lactobacillus casei Bif3'/IV in dry fermented pork loins. International Journal of Food Science and Technology 46: 24912497.

Kolakowska, A.; Deutry, J. 1983. Some comments on the usefulness of 2-thiobarbituric acid (TBA) test for the evaluation of rancidity in frozen fish. Molecular Nutrition and Food Research 27: 513-518.
Kozioł, J.; Skrzypczak, K.; Gustaw, W.; Waśko, A. 2013. Effect of milk protein preparations on growth of Bifidobacterium. Żywność. Nauka. Technologia. Jakość 3: 83-98 (in Polish, with abstract in English).

Lasik, A.; Pikul, J.; Danków, R.; Cais-Sokolińska, D. 2011. The fermentation dynamics of sheep milk with increased proportion of whey proteins. Acta Scientiarum Polonorum, Technologia Alimentaria 10: 155-163.

Liu, H.C.; Chen, W.L.; Mao, S.J.T. 2007. Antioxidant nature of bovine milk ß-lactoglobulin. Journal of Dairy Science 90: 547555.

Lobo, V.; Patil, A.; Phatak, A.; Chandra, N. 2010. Free radicals, antioxidants and functional foods: impact on human health. Pharmacognosy Reviews 4: 118-26.

Mahan, L.K.; Escott-Stump, S. 2000. Krause's Food, Nutrition and Diet Therapy. 10ed. W.B. Saunders, Philadelphia, PA, USA.

Motyl, I.; Klewicka, E.; Libudzisz, Z. 2009a. Lactobacillus casei LOCK 0900. Polish patent application: no. 382760.

Motyl, I.; Klewicka, E.; Libudzisz, Z. 2009b. Lactobacillus casei LOCK 0908. Polish patent application: no. 382761.

Motyl, I.; Klewicka, E.; Libudzisz, Z. 2009c. Lactobacillus paracasei LOCK 0919. Polish patent application: no. 382762.

Pegg, R.B.; Shahidi, F.; Gogan, N.J.; Desilva, S.I. 1997. Elucidation of the chemical structure of preformed cooked cured-meat pigment by electron paramagnetic resonance spectroscopy. Journal of Agricultural and Food Chemistry 44: 416-421.

Pikul, J.; Leszczyński, D.E.; Kummerow, F.A. 1989. Evaluation of three modified TBA methods for measuring lipid oxidation in chicken meat. Journal of Agricultural and Food Chemistry 37: 1309.

Rubio, B.; Martínez, B.; García-Cachán, M.D.; Rovira, J.; Jaime, I. 2008. Effect of the packaging method and the storage time on lipid oxidation and colour stability on dry fermented sausage salchichón manufactured with raw material with a high level of mono and polyunsaturated fatty acids. Meat Science 80: 11821187.

Romero, M.C.; Romero, A.M.; Doval, M.M.; Judis, M.A. 2013. Nutritional value and fatty acid composition of some traditional Argentinean meat sausages. Food Science and Technology 33: 161-166

Sammel, L.M.; Claus, J.R. 2003. Whey protein concentrates effects on pink color development in a cooked ground turkey breast model system. Meat Science 66: 1293-1299.

Simopoulos, A.P. 2002. The importance of the ratio of omega-6/omega-3 essential fatty acids. Biomedicine and Pharmacotherapy 56: 365-379.

Srinivasan, S.; Xiong, Y.L.; Decker, A. 1996. Inhibition of protein and lipid oxidation in beef heart surimi-like material by antioxidants and combinations of $\mathrm{pH}, \mathrm{NaCl}$, and buffer type in the washing media. Journal of Agricultural and Food Chemistry 44: 119-125.

Tong, L.M.; Sasaki, S.; McClements, D.J.; Decker, E.A. 2000. Antioxidant activity of whey in a salmon oil emulsion. Journal of Food Science 65: 1325-1329.

Valencia, I.; Ansorena, D.; Astiasarán, I. 2006. Stability of linseed and antioxidants containing dry fermented sausages: a study of the lipid fraction during different storage conditions. Meat Science 73: 269-277. 
Verma, S.P.; Sahoo, J. 2000. Improvement in the quality of ground chevon during refrigerated storage by tocopherol acetate preblending. Meat Science 56: 403-413.

Worobiej, E.; Wujkowska, A.; Drużyńska, B.; Wołosiak, R. 2008. Antioxidant activity of commercial preparations of whey proteins. Żywność. Nauka. Technologia. Jakość 4: 35-42.

Yi-Chen, Ch.; Nguyen, J.; Semmens, K.; Beamer, S.; Jaczynski, J. 2008. Chemical changes in omega- 3 enhanced farmed rainbow trout (Oncorhynchus mykiss) fillets during abusive temperature storage. Food Control 19: 599-608.
Zanardi, E.; Dorigoni, V.; Badiani, A.; Chizzolini, R. 2002. Lipid and colour stability of Milano- type sausages: effect of packing conditions. Meat Science 61: 7-14.

Zhang, X.; Kong, B.; Xiong, L. 2007. Production of cured meat color in nitrite-free Harbin red sausage by Lactobacillus fermentum fermentation. Meat Science 77: 593-598. 